\title{
Overview of the International Space Station System Level Trace Contaminant Injection Test
}

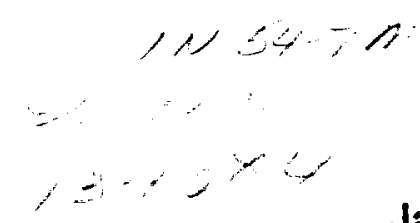

Jay L. Perry and Gerald D. Franks Environmental Control and Life Support Branch - NASAMSFC

Copyright 1997 Society of Automotive Engineers, Inc.

\begin{abstract}
Trace contaminant control onboard the International Space Station will be accomplished not only by the Trace Contaminant Control Subassembly but also by other Environmental Control and Life Support System subassemblies. These additional removal routes include absorption by humidity condensate in the Temperature and Humidity Control Condensing Heat Exchanger and adsorption by the Carbon Dioxide Removal Assembly. The Trace Contaminant Injection Test, which was performed at NASA's Marshall Space Flight Center, investigated the system-level removal of trace contaminants by the International Space Station Atmosphere Revitalization, and Temperature/Humidity Control Subsystems, (November - December 1997). It is a follow-on to the Integrated Atmosphere Revitalization Test conducted in 1996. An estimate for the magnitude of the assisting role provided by the Carbon Dioxide Removal Assembly and the Temperature and Humidity Control unit was obtained. In addition, data on the purity of Carbon Dioxide Removal Assembly carbon dioxide product were obtained to support Environmental Control and Life Support System Air Revitalization Subsystem loop closure.
\end{abstract}

\section{INTRODUCTION}

In the closed environment of a spacecraft, such as the International Space Station (ISS), trace contaminant build-up is a major concern. Contaminants are generated by equipment off-gassing, human metabolic processes, and the metabolic processes of animals. The contaminants, if not removed, will build-up in the cabin atmosphere leading to a heavier contamination load on the on-board water processing equipment. The Trace Contaminant Control Subassembly (TCCS) was designed to remove trace contaminants from the ISS cabin air. Other equipment, such as the Carbon Dioxide Removal Assembly (CDRA), and the Temperature and Humidity Control (THC) Subsystem are designed specifically to remove carbon dioxide and water respectively, from the atmosphere. It is suspected however, that the CDRA and THC will also contribute to the removal of trace chemical of trace chemical contaminants found in the cabin atmosphere. The Trace Contaminant Injection Test (TCIT) was designed to evaluate the CDRA and THC with respect to their ability to remove trace contaminants. ${ }^{1}$ The test is a follow on to the Integrated Atmosphere Revitalization Test conducted in $1996 .{ }^{2}$

\section{TEST CONFIGURATION OVERVIEW}

There are numerous contaminants which may be found within the ISS cabin. The TCIT would be far too complex if all the possible contaminants were tested. That being the case, eight contaminants were chosen to represent the most common types expected. They are the following:

- Methane - a common metabolic by-product, and a very difficult molecule to oxidize

- Ammonia - another common metabolic by-product, and an extremely water soluble chemical

- Carbon Monoxide - A minor metabolic by-product, a biological poison, and a common by-product of incomplete combustion processes

- Carbon Dioxide - the most abundant metabolic byproduct, and the target of CDRA operation

- Methylene Chloride - a common solvent used in the fabrication and electronics industry, a typical off-gas contaminant, and a relatively polar compound

- $m$-Xylene - a common solvent used in the fabrication and electronics industry, a typical off-gas contaminant and a very stable aromatic chemical

- Acetone - a common solvent used in the fabrication and electronics industry, a typical off-gas contaminant and a relatively non-polar chemical

- Methanol - a common solvent used in the fabrication and electronics industry, a typical off-gas contaminant and a highly water soluble chemical

The contaminants were injected into the closed, $175 \mathrm{~m}^{3}$ test chamber at a rate expected to provide equilibrium 
concentrations near the Spacecraft Maximum Allowable Concentration (SMAC) as determined by pretest analysis, and estimated removal efficiencies (Table 1). ${ }^{3}$ Water, nitrogen, carbon dioxide, and oxygen were

Table 1 - Contaminant Injection Rates

\begin{tabular}{|l|l|}
\hline Contaminant & Injection Rate \\
\hline Acetone & $23.63 \mu \mathrm{L} / \mathrm{min}$ \\
\hline Methylene Chloride & $1.92 \mu \mathrm{L} / \mathrm{min}$ \\
\hline Methanol & $9.39 \mu \mathrm{L} / \mathrm{min}$ \\
\hline m-Xylene & $32.46 \mu \mathrm{L} / \mathrm{min}$ \\
\hline Carbon Monoxide & $0.61 \mathrm{~mL} / \mathrm{min}$ \\
\hline Methane & $8.59 \mathrm{~mL} / \mathrm{min}$ \\
\hline Ammonia & $49.2 \mathrm{~mL} / \mathrm{min}$ \\
\hline
\end{tabular}

injected, by a Metabolic Simulator. Nitrogen, oxygen, and carbon dioxide were maintained in the test chamber, at typical atmospheric levels, and water at $50 \%$ relative humidity. The trace contaminant concentrations were then monitored at various points within the test chamber (see - Sample Distribution System).

TRACE CONTAMINANT CONTROL SUBASSEMBLY (TCCS) - The TCCS (Figure 1) utilizes phosphoric acid impregnated granular activated carbon, an oxidation catalyst ( $0.5 \%$ palladium on $3.175 \mathrm{~mm}$ alumina pellets), and granular lithium hydroxide sorbent beds for contaminant removal. The primary oxidation by-products are carbon dioxide and water.

Trace contaminant laden air enters the TCCS from the cabin atmosphere via the high flow leg, and passes through the activated carbon bed at $254.8 \mathrm{Lmin}$ (9 scfm). A portion of this air stream is diverted to the catalytic oxidizer (low flow leg), and the lithium hydroxide beds, at $76.4 \mathrm{~L}$ min $(2.7 \mathrm{scfm})$. Contaminants are oxidized within the catalyst bed, and acidic by-products are removed in the lithium hydroxide bed.

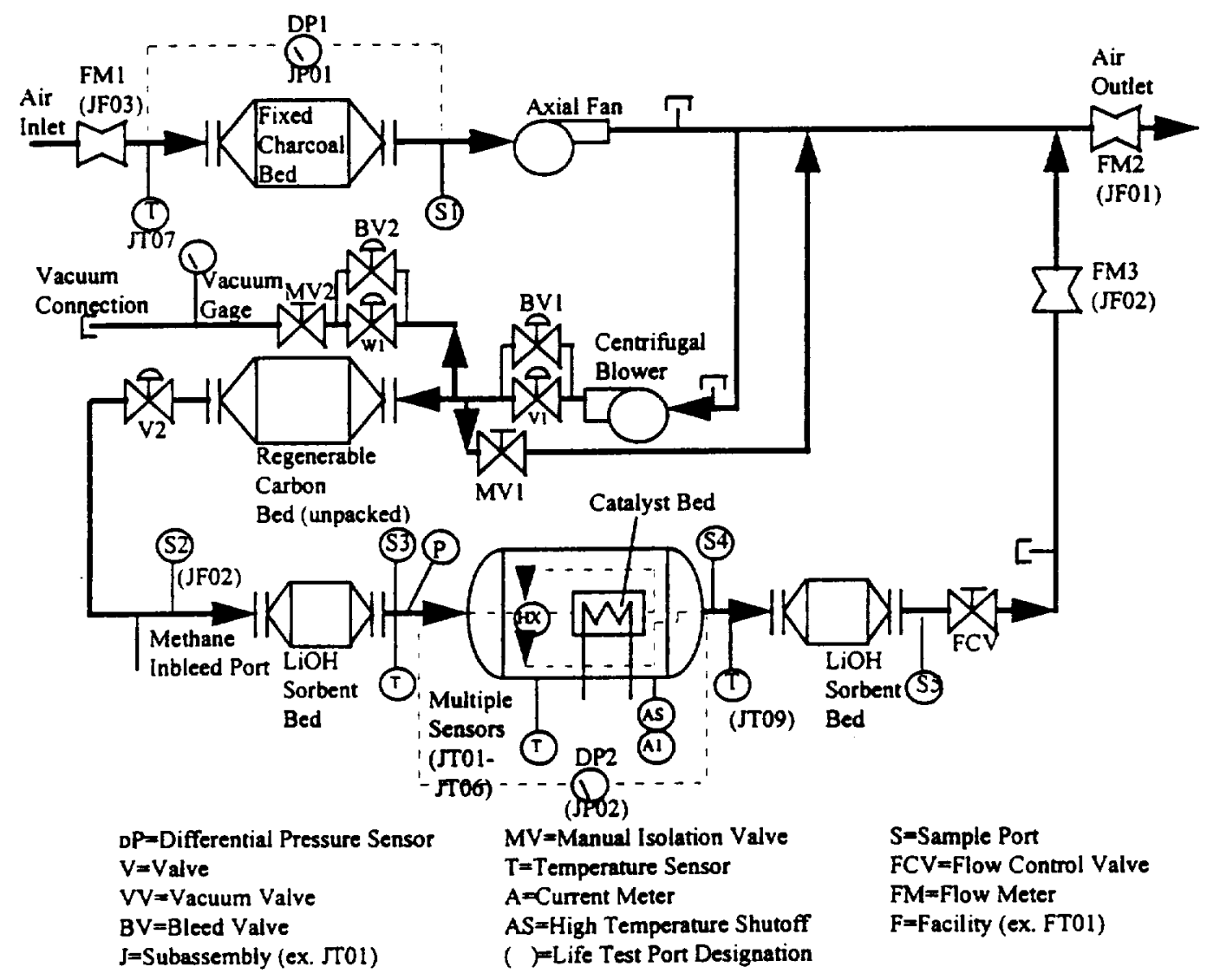

Figure 1 - The Trace Contaminant Control Subassembly

TEMPERATURE AND HUMIDITY CONTROL (THC) The THC controls the ISS cabin temperature and humidity through the use of a Condensing Heat Exchanger ( $\mathrm{CHX})$. During the test, cabin relative humidity was maintained at $50 \%$. This provided enough moisture to maintain a steady condensate stream from the $\mathrm{CHX}$ without overloading the system. Temperature was maintained at approximately $25^{\circ} \mathrm{C}\left(77^{\circ} \mathrm{F}\right)$.
CARBON DIOXIDE REMOVAL ASSEMBLY (CDRA) The CDRA removes excess carbon dioxide from the cabin atmosphere (Figure 2). Air enters the CDRA at 849.4 U min (30 sctm) through a molecular sieve/silica gel desiccant bed. This bed removes all moisture from the air stream before it enters the carbon dioxide sorbent bed. The carbon dioxide sorbent consists of zeolite 5A molecular sieves, which remove carbon dioxide from the dry air stream. After being stripped of carbon dioxide, the air stream passes through a moisture laden 
desiccant bed which was loaded in a previous CDRA cycle. The dry air is saturated with moisture, and the now wet carbon dioxide free air, passes back into the ISS cabin via the THC duct network which circulates at $16,988 \mathrm{~L} / \mathrm{min}(600 \mathrm{scfm})$. This all takes place while a second sorbent bed is being heated, and exposed to a vacuum removing previously loaded carbon dioxide. The carbon dioxide released is either stored in a pressurized vessel for recycling, or dumped to space vacuum. The system then flips cycle, and the process is repeated on the opposite pairs of sorbent and desiccant beds.
Cooling water to the CDRA circulates at $119.1 \mathrm{Kg} / \mathrm{hr}(262$ $\mathrm{lb} / \mathrm{hr}$ ) at a temperature of $15.1^{\circ} \mathrm{C}\left(59.2^{\circ} \mathrm{F}\right)$.

CONTAMINANT INJECTION SYSTEM - A system was developed for injecting contaminants into the TCIT test chamber. There were two basic systems connected to a common manifold. These are the Solvent Injector and the Gas Injector units. Air circulates from the test chamber, through the manifold, and back to the chamber at $424.7 \mathrm{Lmin}(15 \mathrm{scfm})$. The manifold is held at $65^{\circ} \mathrm{C}$ $\left(149^{\circ} \mathrm{F}\right)$ to ensure rapid vaporization of injected contaminants.

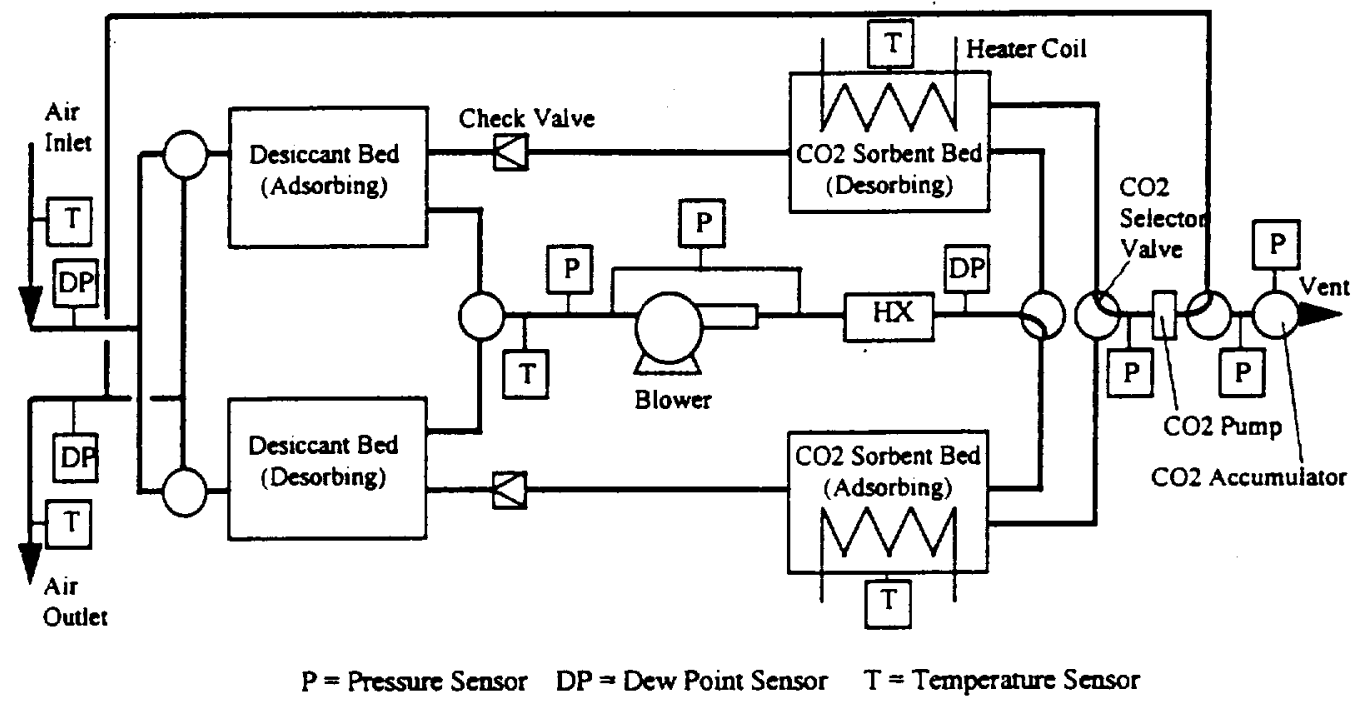

Figure 2 - Carbon Dioxide Removal Assembly

Solvent Iniector - The solvent injector assembly is comprised of four programmable syringe pumps, syringes, solenoid switching valves, and contaminant reservoirs (Figure 3 ). When a syringe injects to its limit,

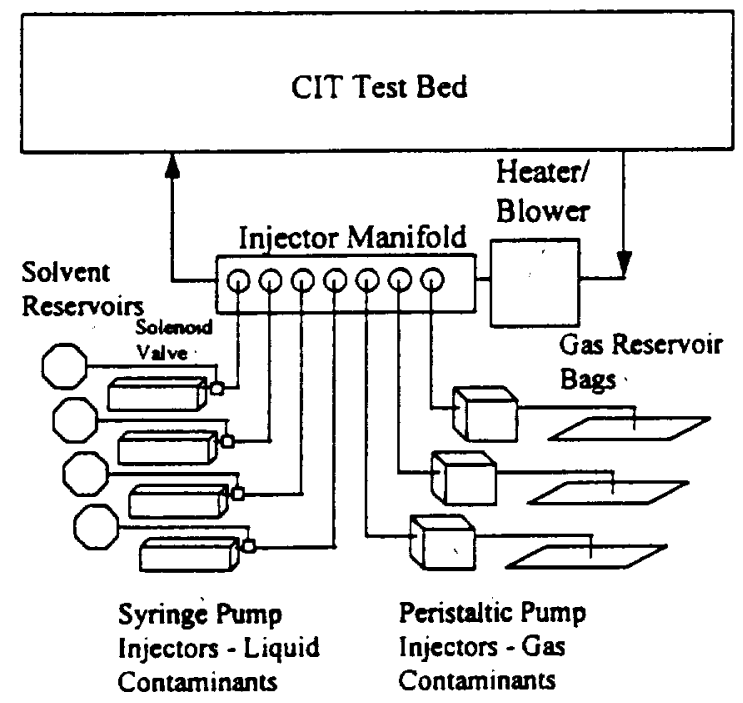

Figure 3 - Contaminant Injector Assembly

the unit automatically cycles into the withdraw mode. When this happens, the solenoid valve switches from syringe pump-test bed plumbing to syringe pumpcontaminant reservoir plumbing. This allows the pump to pull fresh chemicals from the reservoir, and refill the syringe. The solenoid valve then switches again, and the freshly loaded syringe injects into the test bed. This process is repeated for the test duration. Liquid contaminant injection rates are shown in Table 1.

Gas Iniector - The gas injector assembly is more simple than the solvent injector, and requires manual replacement of gas bags containing the contaminant gases (Figure 3). A programmable peristaltic pump is used to meter the gases into the test bed at the appropriate rate. When the bags are nearly empty, they are switched out by test personnel utilizing quick disconnect fittings. Gas contaminant injection rates are shown in Table 1.

CORE MODULE SIMULATOR (CMS) - The CMS is the chamber containing the test equipment. The CMS is a large, cylindrical stainless steel vessel outfitted with facility test equipment. A door at one end of the CMS can be sealed giving a nearly air tight $175 \mathrm{~m}^{3}\left(6180 \mathrm{ft}^{3}\right)$ volume.

Sample Distribution System - Within the CMS is a set of two ten-port manifold valves. These valves are used to select the point from which a sample is to be collected within the CMS/test chamber. One ten port valve was used for the distribution of Gas Chromatograph (GC) samples, the other for distribution of ammonia analyzer samples. 


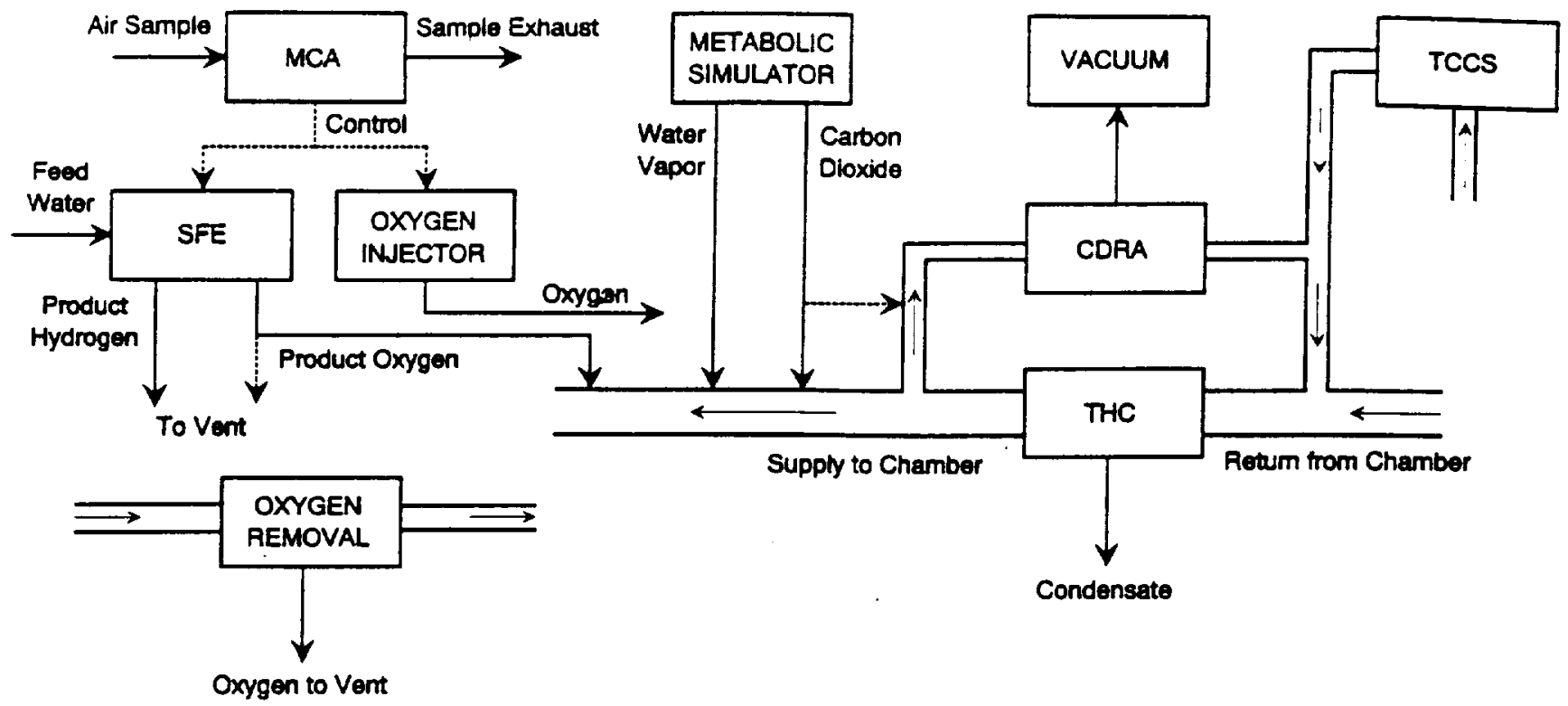

Figure 4 - TCIT Configuration

Sample collection points were the:

- TCCS Outlet (Duct)

- TCCS Outlet (Oxidizer Leg)

- CDRA Outlet

- Rear Chamber

- Mid Chamber

- Front Chamber

- Post CHX

The MCA has an individual sample distribution manifold which is built into the unit. This allows the MCA to draw samples from the following points:

- Post $\mathrm{CHX}$

- Front Chamber

- Rear Chamber

- Post TCCS (Duct)

- Mid Chamber

- CORA Outlet

Additional samples were collected manually from the CDRA accumulator tank to check for trace contaminants in the product $\mathrm{CO}_{2}$. The samples were collected into teflon sample bags, and prepared for analysis. These samples were analyzed by gas chromatography and with a dedicated ammonia analyzer.

ANALYTICAL METHODS - Several techniques were utilized in analyzing TCIT samples. These include online analysis of trace contaminants by Gas Chromatograph (GC), on-line analysis of major constituents in the air by Major Constituent Analyzer (MCA), and ammonia analysis with a dedicated ammonia analyzer. Humidity condensate samples collected from the $\mathrm{THC} / \mathrm{CHX}$ were partially analyzed on-site and sent to a contractor laboratory for methanol, volatile, and alkalinity analyses.

Solvent Contaminants by Gas Chromatograph (GC) Solvents in air were performed by a Hewlett Packard (HP) 5890 Series II GC equipped with an HP $62475 \mathrm{~m} /$ $0.534 \mathrm{~mm}$ Megabore capillary column, and a Flame Ionization Detector (FID). The method parameters utilized were the following:

- Injector Temperature $-250^{\circ} \mathrm{C}\left(482^{\circ} \mathrm{F}\right)$

- Detector Temperature $-225^{\circ} \mathrm{C}\left(437^{\circ} \mathrm{F}\right)$

- Oven Temperature $-30^{\circ} \mathrm{C}\left(86^{\circ} \mathrm{F}\right)$

- Hold Time -6 minutes

- Rate $1-10^{\circ} \mathrm{C}$ per minute

- Final Temperature $1-145^{\circ} \mathrm{C}\left(293^{\circ} \mathrm{F}\right)$

- Final Time - 0 minutes

- Rate $2-20^{\circ} \mathrm{C}$ per minute

- Final Temperature $2-225^{\circ} \mathrm{C}\left(437^{\circ} \mathrm{F}\right)$

- Final Time $2-0$ minutes

- Inlet A pressure - $137.9 \mathrm{kPa}$ (20 psi)

- Inlet B pressure - $137.9 \mathrm{kPa}$ (20 psi)

- Carrier Gas - Helium @ $15 \mathrm{~mL}$ per minute

- Detector - FID

Samples were collected on Tenax/Carbotrap mixed resin tubes for 5 to 15 minutes at a flow rate of $30 \mathrm{~mL}$ per minute. Samples were desorbed for 10 minutes at $400^{\circ} \mathrm{C}\left(752^{\circ} \mathrm{F}\right)$ and a helium carrier flow rate of approximately $15 \mathrm{~mL}$ per minute. Desorption was accomplished with a thermal desorption (ballistic heating) injector assembly. This unit desorbed the sample directly onto the analytical column without the use of cryogenic trapping. Detection limits and SMAC concentrations are the following: 


\begin{tabular}{|c|c|c|}
\hline $\begin{array}{l}\text { Contaminant } \\
\text { Methanol } \\
\text { Acetone } \\
\text { Dichloromethane } \\
\text { m-Xylene } \\
\text { Ammonia } \\
\text { Alkalinity }\end{array}$ & $\begin{array}{c}\text { Detection Limit } \\
6.0 \mathrm{mg} / \mathrm{L} \\
6.9 \mu \mathrm{g} / \mathrm{L} \\
0.36 \mu \mathrm{g} / \mathrm{L} \\
0.19 \mu \mathrm{g} / \mathrm{L} \\
0.03 \mathrm{mg} / \mathrm{L} \\
1.53 \mathrm{mg} / \mathrm{L}\end{array}$ & $\begin{array}{l}\frac{\text { Method }}{\text { EPA } 8015} \\
\text { EPA } 624 \\
\text { EPA } 624 \\
\text { EPA } 624 \\
\text { EPA } 350.3 \\
\text { EPA } 310.1\end{array}$ \\
\hline
\end{tabular}

- EPA Methods (see Additional Sources, belovi).

All samples were handled in compliance with the Analytical Control Test Plan and Microbiological Methods for the Water Recovery Test. This is a Quality Control (QC) document which covers such items as sample collection protocol, chain of custody procedures, and storage/shipping requirements.

\section{TEST OPERATIONS SUMMARY}

INITIAL CONTAMINANT LOADING - To help accelerate reaching an equilibrium of test chamber contaminants, an initial contaminant loading was performed. In this procedure, a known quantity of contaminants was rapidly injected into the test chamber by one of two methods. This injection was accomplished with all contaminant removal equipment off. The chamber was then allowed to come to equilibrium prior to continuous contaminant injection.

Gas Iniection - Rapid gas injection was accomplished by pumping a known quantity of gas directly into the recirculation duct using a high capacity analytical grade pump. The pump is a bellows type assembly with teflon wetted parts.

A known quantity of gas was injected into an evacuated teflon sample collection bag. Quantification was accomplished through the use of calibrated mass flow controllers. Pure contaminant gasses were loaded into the bag using quick disconnect fittings, and were then pumped into the test chamber.

Solvent Iniection - Rapid solvent injection was accomplished by manually injecting a known quantity of pure solvent directly into the recirculation duct using an analytical syringe.

CONTAMINANT INJECTION - Contaminant injection was accomplished through an automated system of syringe pumps, peristaltic pumps, liquid contaminant reservoirs, and teflon holding bags. A thorough description may be found under CONTAMINANT INJECTION SYSTEM (above).

There was no need for solvent reservoir refill since ample volumes of solvent were available at test initiation. Gas contaminant holding bags were checked daily for adequate contaminant supply levels. These bags were replaced as necessary with full holding bags.

Contaminant injection equipment was checked at least three times daily for anomalous conditions (morning. noon, evening). The primary problems observed were bubbles forming in the solvent injection train. These bubbles were easily removed, and involved little down time.

SAMPLE COLLECTION - Sample collection began as the initial task of each work day. Typically, two sets of samples were collected during weekdays, and one set on weekends. Samples were collected at the lower concentration point first, followed by higher concentration points. On weekdays, when mechanical or technical problems arose, fewer than two full sets of samples were collected.

DOCUMENTATION - All procedure implementation, test modification, results, and anomalies were recorded in either the GC log book, or the TCIT Master Log. GC results were recorded by hand as observed, from hard copy computer print-outs, and in electronic format on the GC PC controller.

\section{RESULTS}

During the entire $\mathrm{TCIT}$, each compound was injected into the test chamber at or near their respective target rates presented earlier by Table 1 . As the contaminants were injected, the TCCS, CHX, and CDRA removed them producing the average chamber concentrations summarized by Table 2.

\begin{tabular}{|l|l|l|}
\hline COMPOUND & $\begin{array}{l}\text { INJECTION } \\
\text { RATE } \\
(\mathrm{mg} / \mathrm{h})\end{array}$ & $\begin{array}{l}\text { CHAMBER } \\
\text { CONCENTRATION } \\
\left(\mathrm{mg} / \mathrm{m}^{3}\right)\end{array}$ \\
\hline Acetone & 1118.5 & 39.0 \\
\hline $\begin{array}{l}\text { Carbon } \\
\text { monoxide }\end{array}$ & 46 & 9.1 \\
\hline $\begin{array}{l}\text { Dichloro- } \\
\text { methane }\end{array}$ & 156.8 & 5.4 \\
\hline Methanol & 445.9 & 26.6 \\
\hline m-Xylene & 2916.0 & 87.7 \\
\hline Methane & 368 & 68.9 \\
\hline Ammonia & 600.7 & 8.9 \\
\hline
\end{tabular}

Table 2 - Average TCIT Injection Rates and Chamber Concentrations

Analysis of atmospheric samples collected at the inlet and outlet of the TCCS, CHX, and CDRA in addition to the analysis of humidity condensate allowed for a determination of the relative percentage of the contaminant load controlled by each device. Atmospheric leakage, which was determined to be $0.038 \mathrm{~m}^{3} / \mathrm{h}(0.022$ scfm), also contributed to contaminant removal from the test chamber. A summary of the relative performance of the TCCS, CHX, and CDRA is provided by the following discussion. 


\begin{tabular}{|c|c|c|}
\hline & ;tion Limit & $\begin{array}{l}180 \text { Day } \\
\text { SMAC }\end{array}$ \\
\hline $\begin{array}{l}\text { - Methanol } \\
\text { - } \\
\text { - } \text { Dichloromethane } \\
\text { m-Xylene }\end{array}$ & $\begin{array}{l}5.0 \mathrm{ppm}_{\mathrm{v}} \\
5.0 \mathrm{ppm}_{\mathrm{v}} \\
2.0 \mathrm{ppm}_{\mathrm{v}} \\
5.0 \mathrm{ppm}_{\mathrm{v}}\end{array}$ & $\begin{array}{r}7 \mathrm{ppm}_{\mathrm{v}} \\
22 \mathrm{ppm}_{\mathrm{v}} \\
3 \mathrm{ppm}_{\mathrm{v}} \\
50 \mathrm{ppm}_{\mathrm{v}}\end{array}$ \\
\hline
\end{tabular}

NOTE : Contaminants were measured in an air matrix. Reliable results have been obtained belows the detection limit, but due to limited funding, the method could not be fully developed to give certified limits below those reported above.

Gas Contaminants by GC - Gas contaminants, other than ammonia, were analyzed with the same HP 5890 Series II GC used for solvent analysis, but with a second column and analytical program. The column for this procedure was a Stainless Steel, $60 / 80$ mesh Supelco Carboxen 1000 column of $4.6 \mathrm{~m} \times 0.32 \mathrm{~cm}\left(15^{\prime} \times 1 / 8^{\prime \prime}\right)$. Detection was accomplished by a Thermal Conductivity Detector (TCD). The method parameters utilized were the following:

- Injector Temperature $-150^{\circ} \mathrm{C}\left(302^{\circ} \mathrm{F}\right)$

- Detector Temperature $-200^{\circ} \mathrm{C}\left(392^{\circ} \mathrm{F}\right)$

- Oven Temperature $-35^{\circ} \mathrm{C}\left(95^{\circ} \mathrm{F}\right)$

- Hold Time -7 minutes

- Rate $1-20^{\circ} \mathrm{C}\left(68^{\circ} \mathrm{F}\right)$ per minute

- Final Temperature $1-170^{\circ} \mathrm{C}\left(338^{\circ} \mathrm{F}\right)$

- Final Time - 0 minutes

- Valve open - 50 seconds

- Valve closed - 9 minutes

- Inlet A pressure - $137.9 \mathrm{kPa}$ (20 psi)

- Inlet B pressure - $137.9 \mathrm{kPa}$ (20 psi)

- Carrier Gas - Helium @ 30 mL per minute

- Detector - TCD

- TCD sensitivity - High

Sample injection was accomplished with a gas controlled injector valve, and was injected directly onto the column. Detection limits were the following:

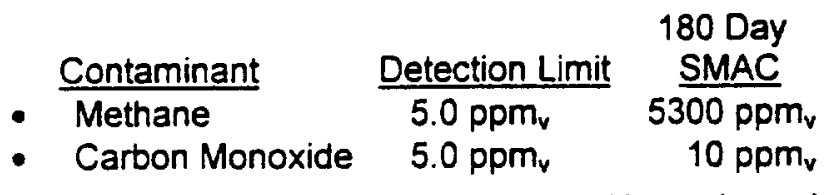

NOTE : contaminants were measured in an air matrix

Major Constituent Analyzer (MCA) - The Major Constituent Analyzer (MCA) measures the predominant gases in the ISS environment - nitrogen, oxygen, water vapor, carbon dioxide, methane, and hydrogen. Originally developed as the Skylab program's metabolic analyzer and most recently used aboard Spacelab, the MCA uses a permanent-magnet, single-focusing mass spectrometer. In operation, a gas sample is collected via a sample delivery system consisting of $3.2 \mathrm{~mm}$ diameter stainless steel tubing. A fraction of the sample is introduced into the MCA through a sintered metal leak.
The gas is ionized with electrons generated from a hot filament. These ions are accelerated into the magnetic analyzer and separated by magnetic field according to their mass-to-charge ratios. Individual Faraday collectors tuned for each of the major constituents amplify the currents generated by the different ions and convert them to voltages which are then processed and reported as partial pressures. The ratio of these partial pressures to the total pressure determines the relative concentration of each gas. The MCA is shown schematically by Figure 5 .

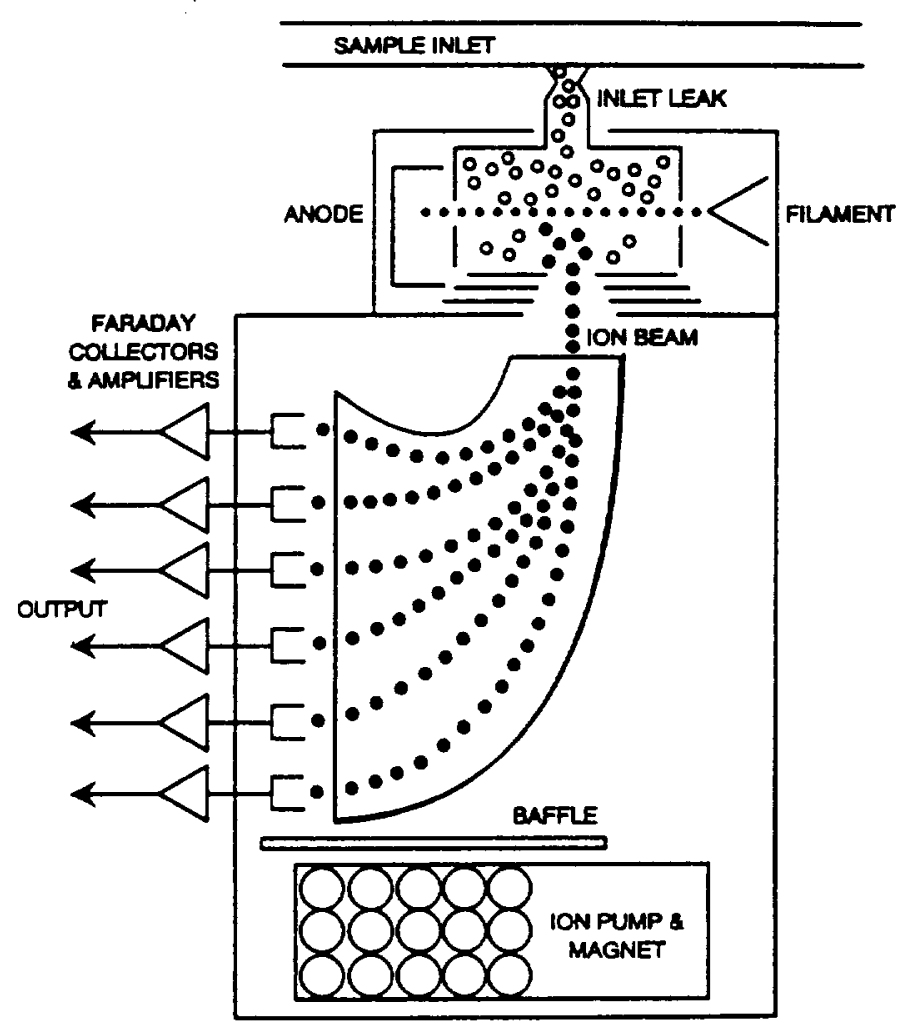

Figure 5 - Simplified MCA Schematic

Ammonia Analyzer - Ammonia was analyzed by a Pioneer in-line diffusion detector with a draw pump. Samples were drawn from the test bed, through the detector, and back into the test bed. The analyzer has the following capability:

- $\begin{array}{lll}\text { Contaminant } & \text { Detection Limit } & \begin{array}{c}180 \text { Day } \\ \text { Smmonia }\end{array} \frac{\text { Spm }_{\mathrm{v}}}{10 \mathrm{ppm}_{\mathrm{v}}}\end{array}$

NOTE : contaminants were measured in an air matrix

Laboratory Samples - Water samples (humidity condensate) were collected at the THC CHX to check for water soluble contaminants. Conductivity, $\mathrm{pH}$, and Total Organic Carbon (TOC) were analyzed on site. Samples for specific contaminants were analyzed at a contractor laboratory. The samples were analyzed utilizing the following methods: 
CONTAMINANT REMOVAL BY THE TCCS - During the test, the overall TCCS average flow rate was $15.46 \mathrm{~m}^{3} / \mathrm{h}$ $(9.10 \mathrm{scfm})$. Of this flow, an average of $4.64 \mathrm{~m}^{3} / \mathrm{h}(2.73$ scfm) flowed through the HTCO assembly. Samples were collected downstream of the HTCO and at the overall TCCS outlet. Concentrations observed at these 2 locations are summarized by Table 3.

\begin{tabular}{|l|l|l|}
\hline \multirow{2}{*}{ COMPOUND } & \multicolumn{2}{|l|}{$\begin{array}{l}\text { CONCENTRATION } \\
\left(\mathrm{mg} / \mathrm{m}^{3}\right)\end{array}$} \\
\cline { 2 - 3 } & After HTCO & $\begin{array}{l}\text { Overall TCCS } \\
\text { Exhaust }\end{array}$ \\
\hline Acetone & 0.52 & 0.71 \\
\hline $\begin{array}{l}\text { Carbon } \\
\text { monoxide }\end{array}$ & 0 & 5.6 \\
\hline $\begin{array}{l}\text { Dichloro- } \\
\text { methane }\end{array}$ & 0 & $<0.35$ \\
\hline Methanol & 2.1 & 14.1 \\
\hline m-Xylene & 2.3 & $<0.43$ \\
\hline Methane & 4.1 & 39.5 \\
\hline Ammonia & 0 & 0 \\
\hline
\end{tabular}

Table 3 - Measured Concentrations Downstream of the TCCS

Analysis of these data indicate that acetone, dichloromethane, $m$-xylene, and ammonia were all very effectively removed by the activated charcoal bed. Removal efficiencies were typically $100 \%$ for all of these compounds. A $98 \%$ efficiency was determined for acetone. The remaining compounds were removed by the HTCO assembly. Methane was removed by the HTCO at an average $93.7 \%$ efficiency while carbon monoxide and methanol were removed at $100 \%$ efficiency.

CONTAMINANT REMOVAL BY THE CHX - Removal of trace contaminants via concurrent absorption in humidity condensate is governed by Henry's Law. By taking a mass balance around the $\mathrm{CHX}$, a relationship for the condensate mole fraction, $x$, as a function of the air mole fraction, $y$, can be determined. This relationship is expressed as Equation 1. ${ }^{4}$

$$
x=y /[(C / A)+(H / P)]
$$

In this equation, $C$ is the condensate removal rate in $\mathrm{g}$ mole/ $h, A$ is the air flow rate in g-mole/h, $H$ is the Henry's Law constant in atmospheres, and $P$ is the total chamber pressure in atmospheres. This relationship assumes that complete equilibrium between the liquid and gas phases in the $\mathrm{CHX}$ is achieved and that there are no enhancements or impediments to achieving equilibrium. As this may not be the case, a shape factor that accounts for liquid phase dissociation and reaction along with heat exchanger geometry must be accommodated. The inclusion of such a factor, $\alpha$, yields Equation 2. Data collected during the TCIT have allowed a better understanding of contaminant removal by the $\mathrm{CHX}$ to be obtained along with estimates of the shape factor.

$$
x=y /[(C / A)+(\alpha H / P)]
$$

Humidity condensate was removed by the $\mathrm{CHX}$ at an average rate of $0.39 \mathrm{Lh}$. Air flow rate averaged approximately $738 \mathrm{~m}^{3} / \mathrm{h}$ (434 scfm). During the test, condensate samples were collected and analyzed. Results from these analyses along with each contaminant's Henry's Law constant are summarized by Table 3.

\begin{tabular}{|l|l|l|}
\hline COMPOUND & $\begin{array}{l}\text { HENRY'S } \\
\text { CONSTANT } \\
(\mathrm{atm})\end{array}$ & $\begin{array}{l}\text { CONDENSATE } \\
\text { LOADING } \\
(\mathrm{mg} / \mathrm{L})\end{array}$ \\
\hline Acetone & 2.38 & 42.2 \\
\hline $\begin{array}{l}\text { Carbon } \\
\text { monoxide }\end{array}$ & 63,430 & 0 \\
\hline $\begin{array}{l}\text { Dichloro- } \\
\text { methane }\end{array}$ & 137.6 & 0.074 \\
\hline Methanol & 0.39 & 154 \\
\hline m-Xylene & 370.1 & 0.25 \\
\hline Methane & 35.390 & 0 \\
\hline Ammonia & 0.94 & 1,080 \\
\hline
\end{tabular}

Table 3 - Contaminant Loading of Humidity Condensate

According to the condensate analyses, ammonia was removed in the $\mathrm{CHX}$ at the highest level followed by methanol, acetone, $m$-xylene, and dichloromethane. Carbon monoxide and methane were not removed at measurable levels, if at all. This observation is supported by considering the magnitude of each contaminant's Henry's Law constant. The larger the constant, the less contaminant is expected to be removed by absorption in condensate.

By using Equation 1 and the average $\mathrm{CHX}$ condensate and air flow rate conditions, estimates for the liquid phase mole fraction based solely on Henry's Law can be obtained. Comparison of this result to the observed loading summarized by Table 3 allows the magnitude of the shape factor to be estimated. A basis of $1 \mathrm{~L}$ of condensate and $1 \mathrm{~m}^{3}$ of air were used for the calculations. A summary of shape factors are provided by Table 4. 


\begin{tabular}{|l|l|}
\hline COMPOUND & $\begin{array}{l}\text { SHAPE } \\
\text { FACTOR } \\
(\alpha)\end{array}$ \\
\hline Acetone & 0.60 \\
\hline Dichloromethane & 0.74 \\
\hline Methanol & 0.38 \\
\hline m-Xylene & 0.998 \\
\hline Ammonia & 0.011 \\
\hline
\end{tabular}

Table 4 - $\mathrm{CHX}$ Shape Factors

These factors indicate that ammonia, methanol, acetone, and dichloromethane absorption by humidity condensate is enhanced over basic Henry's Law assumptions. Ammonia absorption has been demonstrated to be enhanced by liquid phase reactions resulting from elevated carbon dioxide concentration in the atmosphere. ${ }^{5}$ Since carbon dioxide was maintained at approximately $3 \mathrm{~mm} \mathrm{Hg}$ throughout the test, this can explain the enhanced removal by the $\mathrm{CHX}$. Methanol, acetone, and dichloromethane all have some polar character. Therefore, interaction with water via hydrogen bonding can explain the observed enhancement. Xylene, which is non-polar, has practically no enhanced removal over Henry's Law.

CONTAMINANT REMOVAL BY THE CDRA - Contaminant removal by the CDRA was found to vary over time. This variation correlated with the adsorption/desorption cycle of the beds. Overall, the CDRA removed acetone, dichloromethane, methanol, m-xylene, and ammonia. No measurable amount of carbon monoxide or methane was removed. The net removal efficiencies observed for the CDRA are summarized by Table 5.

\begin{tabular}{|l|l|}
\hline COMPOUND & $\begin{array}{l}\text { NET CDRA } \\
\text { EFFICIENCY } \\
(\%)\end{array}$ \\
\hline Acetone & 33.3 \\
\hline $\begin{array}{l}\text { Carbon } \\
\text { monoxide }\end{array}$ & 0 \\
\hline Dichloromethane & 50 \\
\hline Methanol & 33.3 \\
\hline m-Xylene & 52.7 \\
\hline Methane & 0 \\
\hline Ammonia & 43.1 \\
\hline
\end{tabular}

Table 5 - Net CDRA Removal Efficiency
Based upon the observed CDRA exhaust concentrations, it was concluded that the largest measurable removal is provided by the desiccant bed. This was supported by the fact that no contaminants were found in the carbon dioxide product. Although contaminants were removed by the desiccant bed during the adsorption phase at a relatively high efficiency, they were readily evolved from the bed during the desorption phase leading to the reduced net efficiency. This behavior is consistent with previous testing in which it was found that the desiccant bed provides the greatest removal efficiency for trace contaminants such as methanol and acetone. The carbon dioxide adsorbent bed was also found to provide significant contaminant removal in the previous studies. ${ }^{6.7}$

An interesting trend was observed in which the CDRA exhibited a high removal efficiency for acetone and $\mathrm{m}$ xylene during the early phases of the test. After about 72 hours, the net efficiency for acetone began to decrease. A similar decrease was observed for $\mathrm{m}$-xylene after 96 test hours. This observation indicated a gradual loading of the CDRA beds to breakthrough.

OVERALL CONTAMINANT REMOVAL SUMMARY Based upon the observed contaminant removal by the TCCS, CHX, CDRA, and atmospheric leakage, the overall percentage of trace contaminant removal contributed by each route can be calculated. These percentages are summarized by Table 6 .

\begin{tabular}{|l|l|l|l|l|}
\hline \multirow{2}{*}{ COMPOUND } & \multicolumn{4}{|l|}{ OVERALL CONTAMINANT } \\
& \multicolumn{4}{|l|}{ REMOVAL (\%) } \\
\cline { 2 - 5 } & CORA & TCCS & CHX & LEAK \\
\hline Acetone & 42.6 & 55.7 & 1.6 & 0.1 \\
\hline $\begin{array}{l}\text { Carbon- } \\
\text { monoxide }\end{array}$ & 0 & 99.2 & 0 & 0.8 \\
\hline $\begin{array}{l}\text { Dichloro- } \\
\text { methane }\end{array}$ & 52.9 & 47.0 & $\begin{array}{l}0.00 \\
4\end{array}$ & 0.1 \\
\hline Methanol & 62.4 & 25.0 & 12.4 & 0.2 \\
\hline $\begin{array}{l}\text { m-Xylene } \\
\text { Methane }\end{array}$ & 54.2 & 45.7 & 0.00 & 0.1 \\
\hline Ammonia & 22.1 & 22.8 & 55.0 & 0.06 \\
\hline
\end{tabular}

Table 6 - Contaminant Loading of Humidity Condensate

As shown by Table 6, the CDRA and the $\mathrm{CHX}$ provide a substantial assist to the TCCS for removing trace contaminants from a spacecraft cabin atmosphere. The role of atmospheric leakage is very small by comparison. Overall, the TCCS provides control for the entire methane and carbon monoxide load because of its catalytic oxidation capability. The CDRA and TCCS 
provide comparable control for most other compounds; however, some water soluble compounds are better controlled by the CDRA. The $\mathrm{CHX}$ provides a very significant contribution mainly for ammonia and low molecular weight, polar compounds.

\section{CONCLUSIONS}

Based upon the results obtained during the TCIT, conclusions which can be made are the following:

1. The TCCS receives significant assistance from the CDRA and $\mathrm{CHX}$ for removing trace contaminants from the cabin atmosphere.

2. The primary compounds removed by the $\mathrm{CHX}$ are ammonia and water soluble compounds.

3. Contaminant removal via humidity condensate absorption follows an enhanced Henry's Law relationship for ammonia and polar organic compounds.

4. The TCCS is the primary removal means for methane and carbon monoxide.

5. Contaminant removal by the CDRA is cyclic and can decrease over time as the sorbent beds become increasingly loaded.

\section{REFERENCES}

1. J.D. Tatara and J.L. Perry; International Space Station Trace Contaminant Injection Test, Revision $A$, NASA Test Requirements Document, January 1997.

2. Perry, J.L.; Franks, G.D.; and Knox, J.C.; Intermational Space Station Program Phase III Integrated Atmosphere Revitalization Subsystem Test Final Report, NASA TM-108541; NASA George C. Marshall Space Flight Center: MSFC, Alabama; August 1997.

3. James, J.T.; Spacecraft Maximum Allowable Concen-trations for Airborne Contaminants, JSC 20584; NASA Lyndon B. Johnson Space Center; Houston, Texas; February 1995.

4. Perry, J.L.; Trace Contaminant Control Simulation Computer Program-Version 8.1. NASA Technical Memorandum 108457. NASA, George C. Marshall Space Flight Center: MSFC, Alabama; May 1994, p. 26.

5. Kissinger, L.D. and Verostko, C.E.; Inherent Ammonia Removal Potential of the Space Shuttle Orbiter Condensing Heat Exchanger. JSC-08797. NASA, Lyndon B. Johnson Space Center. Houston, Texas; August 23, 1976.

6. Zeppa, S.J.; Molecular Sieve Contaminant Characterization Test Report. LMSC/F280519. Lockheed Missiles and Space Co., Inc.: Sunnyvale, California; September 5, 1991.

7. Ray, C.D.; Skylab Atmospheric Contamination Control. NASA TM X-64900. NASA, George C. Marshall Space Flight Center. MSFC, Alabama; November 1974, pp. 7, 14-22.

\section{ADDITIONAL SOURCES}

A. Traweek and J.D. Tatara (editors); Analytical Control Test Plan and Microbiological Methods for the Water Recovery Test. NASA Technical Memorandum \#108473.

B. RKI Instruments; Pioneer Gas Monitor Operator's Manual, \#71-0027RK, April 1997.

C. Hale, D.B. and Duello, T.J., PhD; Comprehensive Quality Assurance Plan, SAL-QC-REV 3, January 1996.

D. Methods for Chemical Analysis of Water and Wastes, United States Environmental Protection Agency, Environmental Monitoring and Support Laboratory, 1983 or later.

E. TCIT GC Logbook, NASAMMSFC/EL63 Documentation, March 1996-December 1997.

F. TCIT Master Logbook, NASAMMSC/EL63 Documentation, 1997.

\section{DEFINITIONS, ACRONYMS, ABBREVIATIONS}

$\begin{array}{ll}{ }^{\circ} \mathrm{C} & \text { Degrees Centigrade } \\ { }^{\circ} \mathrm{F} & \text { Degrees Fahrenheit } \\ \mu \mathrm{m} / \mathrm{min} & \text { Microliters per Minute } \\ \text { ARS } & \text { Atmosphere Revitalization Subsystem } \\ \text { CDRA } & \text { Carbon Dioxide Removal Assembly } \\ \text { CHX } & \text { The Condensing Heat Exchanger } \\ \text { cm } & \text { Centimeters } \\ \text { CMS } & \text { Core Module Simulator } \\ \text { ECLSS } & \text { Environmental Control and Life Support Syst. } \\ \text { EPA } & \text { Environmental Protection Agency } \\ \text { FID } & \text { Flame lonization Detector } \\ \text { GC } & \text { Gas Chromatograph } \\ \text { IART } & \text { Integrated Air Revitalization Test } \\ \text { ISS } & \text { International Space Station } \\ \text { Kg/hr } & \text { Kilograms per Hour } \\ \text { L/hr } & \text { Liters per Hour } \\ \text { L/min } & \text { Liters per Minute } \\ \text { Ib/hr } & \text { Pounds per Hour } \\ \text { m } & \text { Meters } \\ \text { m }{ }^{3 / h r} & \text { Cubic Meters per Hour } \\ \text { MCA } & \text { Major Constituent Analyzer } \\ \text { mL/min } & \text { Milliliters per Minute } \\ \text { mm } & \text { Millimeters } \\ \text { MSFC } & \text { Marshall Space Flight Center } \\ \text { NASA } & \text { National Aeronautics and Space Admin. } \\ \text { PC } & \text { Personal Computer } \\ \text { ppmy } & \text { Parts per Million by Volume } \\ \text { QC } & \text { Quality Control } \\ \text { scfm } & \text { Standard Cubic Feet per Minute } \\ \text { SMAC } & \text { Spacecraft Maximum Allowable Concentration } \\ \text { TCCS } & \text { Trace Contaminant Control Subassembly } \\ \text { TCD } & \text { Thermal Conductivity Detector } \\ \text { TCIT } & \text { Trace Contaminant Injection Test } \\ \text { THC } & \text { Temperature and Humidity Control } \\ \text { TOC } & \text { Total Organic Carbon } \\ & \\ & \end{array}$

